\title{
Depresjon og kardiovaskulær sykdom - er det en sammenheng?
}

\author{
Sammendrag \\ Bakgrunn. Depresjon er assosiert med \\ høyere risiko for kardiovaskulære hen- \\ delser. Artikkelen gir en oversikt over \\ data fra kohort- og intervensjonsstu- \\ dier og mulige patogenetiske meka- \\ nismer.
}

Materiale og metode. Artikkelen er basert på litteraturgjennomgang fra et ikke-systematisk søk i Medline.

Resultater. I epidemiologiske studier av pasienter utenfor sykehus med klinisk depresjon er det rapportert økt risiko for kardiovaskulære hendelser. Mulige mekanismer som kan forklare $ø k t$ kardiovaskulær risiko, er økt forekomst av usunne livsstilsfaktorer, systemisk inflammasjon, endokrin og autonom dysfunksjon, økt platereaktivitet eller endoteldysfunksjon. Medikamentell antidepressiv behandling har ikke vært vist å redusere risiko for kardiovaskulære hendelser.

Fortolkning. Leger bør være oppmerksomme på betydningen av depresjon for kardiovaskulær risiko.

\author{
Gunnar Einvik \\ geinvik@online.no \\ Medisinsk divisjon \\ Akershus universitetssykehus \\ 1478 Lørenskog \\ og \\ Institutt for sykehusmedisin \\ Universitetet i Oslo

\section{Toril Dammen} \\ Psykiatrisk divisjon \\ Oslo universitetssykehus, Ullevål \\ og \\ Avdeling for atferdsfag \\ Institutt for medisinske basalfag \\ Universitetet i Oslo \\ Torbjørn Omland \\ Medisinsk divisjon \\ Akershus universitetssykehus \\ og \\ Institutt for sykehusmedisin \\ Universitetet i Oslo
}

Til tross for fallende insidens utgjør kardiovaskulære sykdommer, som akutt og stabil koronarsykdom, cerebrovaskulær sykdom og perifer arteriell sykdom, den hyppigste dødsårsak i Europa, inkludert Norge $(1,2)$. De er også forbundet med redusert livskvalitet, hyppige sykehusinnleggelser og et betydelig ressursforbruk (1). Tidlig diagnostisering og forebyggende behandling rettet mot etablerte kardiovaskulære risikofaktorer som overvekt, røyking, hypertensjon, hyperlipidemi og diabetes er en viktig del av hverdagen til mange norske leger. I nye norske retningslinjer for individuell primærforebygging av hjerte- og karsykdom nevnes psykososiale forhold, blant annet depresjon, som tilleggsfaktorer som bør tas med i vurdering av kardiovaskulær risiko (3). Denne artikkelen gir en oversikt over relevant litteratur om assosiasjon mellom depresjon og kardiovaskulær sykdom, med vekt på om det er en effekt av terapeutiske tiltak og mulige felles patogenetiske mekanismer.

\section{Materiale og metode}

Det er gjort et ikke-systematisk søk i Medline etter engelskspråklige originalartikler og metaanalyser som er publisert i perioden 1998-2008. Litteraturgjennomgangen er en del av et pågående prosjekt med flere prospektive delstudier, der TO er prosjektansvarlig innen kardiologi og TD innen psykosomatikk. På bakgrunn av forfatternes generelle erfaring innen emnet er et utvalg av referanser funnet ved søket samt enkelte relevante artikler fra 2009, omtalt i denne artikkelen.

\section{Epidemiologi}

Assosiasjonen mellom depresjon eller depressive symptomer og kardiovaskulær sykelighet og død har vært undersøkt i over 40 populasjonsbaserte kohortstudier de to siste tiårene. Funnene $\mathrm{i}$ disse studiene har vært vurdert $\mathrm{i}$ to metaanalyser $(4,5)$. I studier med koronarrelaterte endepunkter er relativ risiko (RR) for hendelser hos deprimerte beregnet til 1,8 (95\% KI 1,5-2,1) sammenliknet med ikke-deprimerte (4). Ved inklusjon av kun studier som justerer for etablerte risikofaktorer er RR 1,9 (95\% KI $1,5-2,4)$. Et sammendrag av ti studier som vurderte cerebrovaskulær sykdom som endepunkt viser RR 1,4 (95\% KI 1,2-1,8) (5). Felles for metaanalysene er at de bedømte depresjon som en dikotom variabel og inkluderte pasienter utenfor sykehus. Det synes å være en dose-respons-effekt, da pasienter med klinisk diagnostisert alvorlig depressiv episode hadde høyere risiko for kardiovaskulær sykdom enn personer med selvrapporterte depressive symptomer $(4,5)$.

Mange prospektive studier har screenet pasienter med akutt eller stabil koronarsykdom for depresjon og fulgt dem opp med tanke på nye kardiovaskulære hendelser. Prevalensen av klinisk diagnostisert depressiv lidelse målt innen tre uker i etterkant av et hjerteinfarkt er høy, 5-47\% (6). To metaanalyser med delvis sammenfallende inklusjon av studier rapporterer henholdsvis en justert oddsratio for ny kardiovaskulær hendelse på 2,0 (95\% KI 1,3-2,9) (6) og hasardratio for død på $1,8(95 \% \mathrm{KI} 1,3-2,4)$ (7) ved depresjon. I disse analysene hadde det liten betydning om depresjon var definert som en klinisk diagnose basert på diagnostisk intervju eller definert $i$ henhold til en gitt skår på selvrapporterte spørreskjemaer.

Til tross for statistisk signifikante assosiasjoner og et mulig dose-respons-forhold, er

\section{Hovedbudskap}

- Depresjon kan være en uavhengig risikofaktor for kardiovaskulær sykdom

- Det er ikke vist at antidepressiv behandling påvirker denne risiko$ø$ kningen

- Det er flere sammenfallende patogenetiske mekanismer ved aterosklerose og depresjon 
det ikke åpenbart at det er en kausal sammenheng mellom depresjon og kardiovaskulær sykdom. Andre kriterier for kausalitet innbefatter blant annet kontroll av mulige konfunderende faktorer, effekt av terapeutiske tiltak, og en biologisk plausibel patogenetisk mekanisme. På disse områdene er tilgjengelig kunnskap i dag usikker.

\section{Konfunderende faktorer}

Forekomsten av ugunstige livsstilsfaktorer som røyking, usunt kosthold og lav fysisk aktivitet (8), samt dårlig etterlevelse av medikamentbruk (9), er høyere blant pasienter med depresjon. Disse faktorene har betydning for forekomsten av kardiovaskulær sykdom, men er kun i varierende grad kontrollert for i publiserte studier.

\section{Terapeutiske studier}

E-tabell 1 gir en oversikt over studier vi har funnet med kardiovaskulære endepunkter ved antidepressiv behandling (10-19). Det er publisert få randomiserte placebokontrollerte studier som tester hvorvidt antidepressiv behandling påvirker insidens av kardiovaskulære hendelser hos pasienter med klinisk diagnostisert depresjon og etablert koronarsykdom. I to studier med henholdsvis kognitiv terapi og mirtazapin som intervensjon har kardiovaskulære hendelser vært det primære endepunkt $(10,11)$. Det er også tilgjengelige data om slike hendelser fra studier om kardiovaskulær sikkerhet ved bruk av selektive serotoninreopptakshemmere (SSRI) $(12,13)$. I disse fire studiene varierer insidens av kardiovaskulære hendelser i området $4-24 \%$, men det er ingen signifikante forskjeller mellom kontroll- og intervensjonsgruppene (e-tab 1, 10-14) Alle studiene rapporterer en statistisk signifikant bedring i subjektive og objektive mål for depresjon og livskvalitet. I den største studien antyder en post hoc-analyse at SSRI-midler som tilleggsbehandling til kognitiv terapi kan være gunstig med henblikk på kardiovaskulære hendelser (14).

I pasient-kontroll-studier er det varierende funn av risiko for hjerteinfarkt ved bruk av antidepressiver (e-tab 1, 15-19). To studier basert på kliniske materialer viser at bruk av henholdsvis SSRI-midler eller antidepressiver generelt kan være assosiert med lavere forekomst av hjerteinfarkt $(15,16)$. I to større materialer basert på registeropplysninger var forekomsten av hjerteinfarkt høyere blant brukere av SSRI-midler, enn blant ikke-brukere $(17,18)$, men funnet var statistisk signifikant kun i den ene studien (18). Disse pasient-kontroll-studiene har i liten grad justert for andre risikofaktorer, og det er ikke individuelle vurderinger av forekomst eller alvorlighetsgrad av depresjon. Det er derfor stor usikkerhet om hvorvidt gruppene er likt sammensatt, og utsagnskraften til konklusjonene er begrenset. En kohortstudie av pasienter innlagt etter selvmordsforsøk viste signifikant lavere kardio- vaskulær dødelighet blant dem som brukte SSRI-midler (19).

Depresjon er en hyppig tilstand i etterkant av hjerneslag, men til tross for mange intervensjonsstudier der depresjonsnivå, funksjonsnivå og livskvalitet er endepunkter, har vi ikke funnet data om kardiovaskulære endepunkter ved antidepressiv behandling etter hjerneslag.

\section{Mulige patogenetiske mekanismer Inflammasjon}

Majoriteten av kardiovaskulære hendelser initieres av ruptur eller erosjon av et vulnerabelt aterosklerotisk plakk. Blant faktorer som utløser en slik hendelse, står inflammasjon sentralt (20). Konsentrasjonen av en rekke systemiske inflammasjonsmarkører, som blant annet C-reaktivt protein (CRP), interleukin-6 og proteiner i tumornekrosefaktorfamilien, er assosiert med risiko for nye kardiovaskulære hendelser eller residiv av slike $(21,22)$, spesielt ved påvist aterosklerose (23).

Forskningen på biologiske mekanismer og markører ved depresjon er omfattende. Dyreeksperimentelle forsøk, in vitro-studier og kliniske studier er blitt utført for å undersøke hvorvidt inflammasjon kan spille en rolle (24). I en nylig utgitt metaanalyse angis det at nivået av CRP og de monocyttderiverte cytokinene interleukin-1 og interleukin-6, er økt ved depresjon (25). Et høyt nivå av slike cytokiner kan påvirke stemningsleie og følelser via endret serotoninmetabolisme, hormonproduksjon og nevrotrope vekstfaktorer $(24,26)$.

Betydningen av økt inflammasjon for kardiovaskulære hendelser hos deprimerte har vært vurdert $i$ to prospektive studier. I en kohort av hjertefriske eldre var grad av depressive symptomer positivt korrelert med CRP. Til tross for denne innbyrdes sammenhengen var både depresjon og CRP uavhengig assosiert med insidens av iskemisk hjerneslag (27). En prospektiv pasient-kontrollstudie viste tilsvarende funn for koronare hendelser (28). Hos pasienter med etablert kardiovaskulær sykdom er det gjennomgående påvist økt mengde av inflammasjonsmarkører, men uten forskjell mellom deprimerte og ikke-deprimerte $(29,30)$, muligens med unntak av pasienter med hjertesvikt, der mengden av tumornekrosefaktor- $\alpha$ er høyere blant deprimerte (31).

\section{Endokrine endringer}

\section{og autonom dysfunksjon}

Regulering av hypothalamus-hypofyse-binyrebark-aksen og det autonome nervesystem er anatomisk og funksjonelt knyttet til hypothalamus, som mottar overordnede signaler fra blant annet amygdala og det limbiske system i tillegg til sensoriske signaler fra perifere vev via hjernestammen. Disse systemene er fylogenetisk en del av individets tilpasning til ytre fysiske og psykiske belastninger, og skal blant annet kunne initiere gunstige sirkulatoriske reaksjoner i krisesituasjoner. Hyppige eller sterke aktiveringer av systemet kan føre til takykardi, hypertensjon, økt stressreaktivitet og endoteldysfunksjon. Dette er faktorer som over tid er belastende for myokard og endotel, og bidrar til økt risiko for kardiovaskulær sykdom gjennom arytmier eller plakkskade (32).

Ved depresjon er det påvist forstyrrelser i reguleringen av dette systemet, med tegn på kronisk aktivering, som økt mengde kortikotropinfrigjørende hormon, nedsatt kortisolrespons og glukokortikoidreseptorfølsomhet (33), økt sympatikus- og lavere parasympatikusaktivitet (34).

I to studier av deprimerte pasienter har man undersøkt assosiasjonen mellom endringer i disse systemene og kardiovaskulære hendelser. Lav parasympatisk aktivitet, målt ved hjertefrekvensvariabilitet, er påvist å være en risikofaktor for kardiovaskulær mortalitet, også blant deprimerte $(35,36)$.

\section{Endoteldysfunksjon}

\section{og protrombotiske faktorer}

Ved akutte kardiovaskulære hendelser har egenskaper knyttet til endotelceller, blodplater og koagulasjonsfaktorer betydning for trombedanning $(37,38)$. Endoteldysfunksjon kan også være en viktig mediator for risikofaktorer som røyking og overvekt i patogenesen til aterosklerose. Endotelfunksjon kan undersøkes in vivo ved invasive eller ikke-invasive tester. Også flere sirkulerende markører som selektiner, adhesjonsmolekyler, tromboksan, fibrinogen, D-dimer og von Willebrands faktor kan være aktuelle for å bedømme endotel-og blodplatefunksjon, og er assosiert med fremtidig risiko for kardiovaskulær sykdom (39-41).

Slike mål for endotelfunksjon har vært undersøkt i noen få studier av deprimerte pasienter. To studier har vist tegn til perifer endotelial dysfunksjon hos deprimerte (42, 43 ), men dette ble ikke bekreftet ved en studie av koronar vasoreaktivitet (44). Nivået av intercellulært adhesjonsmolekyl 1 er høyere hos deprimerte pasienter med akutt koronar sykdom, sammenliknet med andre pasienter med akutt koronar sykdom (45, 46). Videre er det påvist større platereaktivitet hos deprimerte sammenliknet med ikkedeprimerte $(46,47)$.

Serebruany og medarbeidere har undersøkt serotonins rolle ved platereaktivitet hos pasienter med kardiovaskulær sykdom, og påvist en lavere reaktivitet ved bruk av SSRI-midler (48, 49). En oversikt over mindre intervensjonsstudier av deprimerte pasienter $(\mathrm{n}<50)$, både med og uten etablert kardiovaskulær sykdom, antyder at endringer i blodplatefunksjon relatert til depresjon normaliseres ved bruk av antidepressiver som påvirker serotoninomsetningen. Det varierer derimot hvorvidt platereaktivitet øker eller reduseres ut ifra hvilket funksjonsmål som har vært studert (50). Data fra en place- 
bokontrollert studie med SSRI-midler hos deprimerte pasienter med etablert hjertesykdom viste bedret endotelfunksjon og statistisk signifikant reduksjon av CRP etter 20 ukers behandling (51).

\section{Diskusjon}

Epidemiologiske data støtter at depresjon kan være en risikofaktor for kardiovaskulær sykdom. Dette kan i stor grad skyldes økt forekomst av tradisjonelle kardiovaskulære risikofaktorer som røyking og fysisk inaktivitet, men det er i tillegg holdepunkter for at biologiske funksjonsendringer ved depresjon påvirker det kardiovaskulære system.

En sentral hypotese for å forklare en slik biologisk sammenheng, er at risikofaktorer for depresjon, som for eksempel genetisk predisposisjon, negative livshendelser eller lav omsorgsgrad i barndom, kan utløse inflammatoriske, endokrine og nevrofysiologiske forandringer i sentralnervesystemet $(52,53)$ (fig 1). Hos disponerte pasienter kan samvirkning mellom disse patogenetiske mekanismene bidra til å utvikle et kronisk økt stressnivå, der nye negative livshendelser lettere kan utløse klinisk depresjon og forbigående øke kardiovaskulær risiko.

Ut i fra dagens kunnskap kan man allikevel ikke fastslå om de påviste biologiske forandringer ved depresjon er årsak til, eller konsekvens av, depresjon. Vurderingen blir ytterligere komplisert av at virkningsmekanismene sannsynligvis er bidireksjonale. Et hjerneslag eller hjerteinfarkt vil hos mange være en akutt psykososial belastning som kan utløse depressive episoder, og andre risikofaktorer som overvekt vil i større grad enn depresjon kunne påvirke for eksempel inflammasjon (54).

Det er ikke holdepunkter for at medikamentell antidepressiv behandling reduserer kardiovaskulær risiko hos deprimerte, men noen resultater kan tyde på at SSRI-midler kan ha gunstig effekt på protrombotiske faktorer og inflammasjonsmarkører (48, 49, 51). Dette har dog kun vært undersøkt hos pasienter noe tid etter akutte hendelser (ca. 30 dager) eller ved stabil koronarsykdom, og ytterligere data behøves for å vurdere betydningen av disse funnene.

Den individuelle variasjonen i fenotype og klinisk forløp av depresjon gjør at sammenlikning av populasjoner og studier er vanskelig. Ved punktundersøkelser av depresjon, enten ved intervju eller spørreskjema, vet man ikke om det er en langvarig kronisk belastning eller nye negative livshendelser som utgjør den økte risikoen.

I denne oversikten har de fleste studier omhandlet koronarsykdom. Selv om den aterosklerotiske prosessen likner, kan man ikke direkte overføre resultater i disse studiene til å gjelde cerebrovaskulær sykdom eller perifer arteriell sykdom.

Vi mener at videre forskning bør vektlegge den rolle biologiske faktorer spiller ved de-

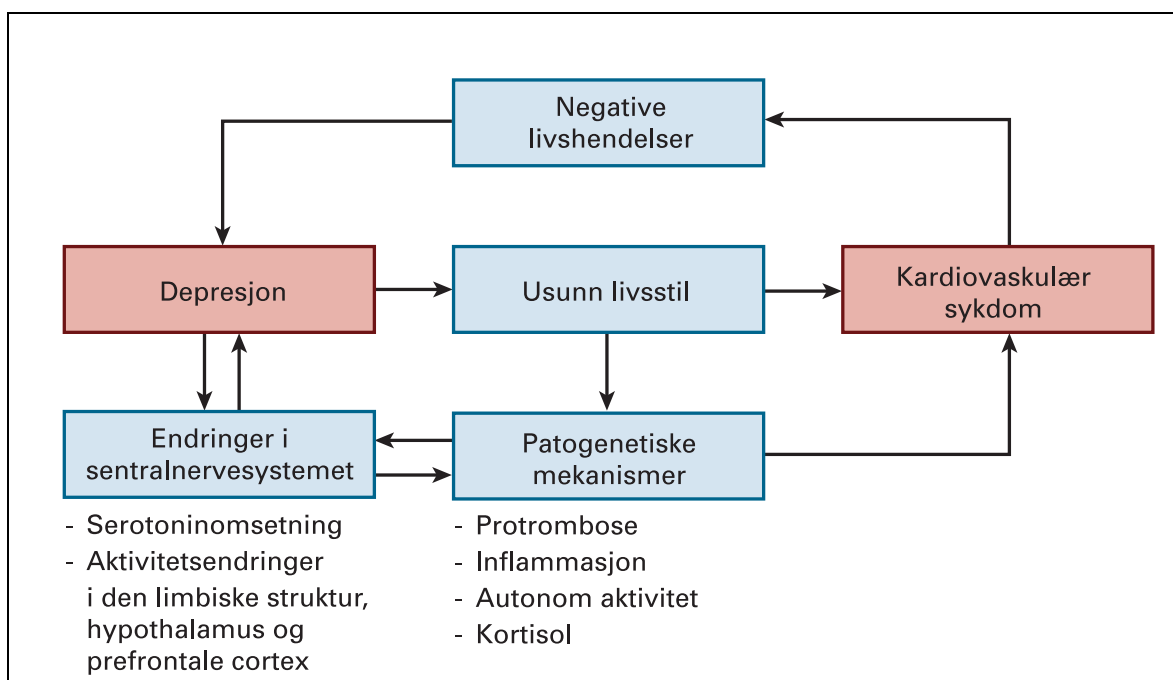

Figur 1 Modell for bidireksjonell påvirkning mellom depresjon og kardiovaskulær sykdom. Karakteristisk atferd (inaktivitet/usunt kosthold/røyking) og biologiske endringer (den hypotalamohypofysære akse/hjernens signalstoffer) ved depresjon kan påvirke patogenetiske mekanismer for kardiovaskulær sykdom. Depressive symptomer kan utløses eller opprettholdes av kardiovaskulære hendelser

presjon, blant annet ved at psykologiske mål i større grad inkluderes i prospektive kardiovaskulære studier. Fordi pasienter med depresjon er en heterogen gruppe, kan man tenke seg at undergrupper har spesifikke fysiologiske endringer som kan knyttes til kardiovaskulær risiko. Hos slike pasienter kan også nye terapeutiske tilnærminger bli aktuelt, som antiinflammatorisk behandling, eller medikamenter med innvirkning på hypothalamushypofyse-binyre-aksen $(55,56)$.

I den praktiske hverdag bør klinikeren med ansvar for deprimerte pasienter ha lav terskel for å vurdere om det foreligger opphopning av etablerte kardiovaskulære risikofaktorer: røyking, lav fysisk aktivitet usunt kosthold og overvekt. Det er et poeng at slike livsstilsfaktorer til dels kan være en konsekvens av depressive symptomer som anhedoni og initativløshet eller vanlige bivirkninger av medikamentell antidepressiv behandling, og at forebyggende tiltak derfor bør ta hensyn til psykiatrisk komorbiditet for å oppnå ønsket effekt.

Hos hjerte- og slagpasienter er depresjon en hyppig komorbid diagnose, som medfører lavere livskvalitet, og høyere risiko for residiv av kardiovaskulære hendelser. American Heart Association har nylig publisert en anbefaling for screening og behandling av depresjon hos pasienter med koronarsykdom, men den nevner spørreskjemaer som ikke er i daglig bruk i Norge (57). Enkle alternative screeninginstrumenter for depresjon, slik som Montgomery Aasberg Depression Rating Scale (MADRS) eller Hospital Anxiety and Depression Scale (HADS), kan identifisere pasienter med depresjon som bør følges opp i etterkant av akutte kardiovaskulære hendelser. Ved behandlingsindikasjon følges vanlige retningslinjer (58).

\section{Konklusjon}

Depresjon er i epidemiologiske studier assosiert med økt insidens av kardiovaskulære hendelser, men det er ikke vist at medikamentell antidepressiv behandling reduserer denne insidensen. Assosiasjonen skyldes mest trolig en kombinasjon av ugunstige livsstilsfaktorer, men der depresjonsspesifikk inflammasjon, endokrin eller autonom dysfunksjon og protrombotisk tendens kan bidra til den økte risikoen.

Oppgitte interessekonflikter: Torbjørn Omland har i løpet av de siste fem år mottatt reisestøtte og/ eller honorarer fra AstraZeneca, Lundbeck, MSD, Otsuka, Pfizer, Roche og sanofi-aventis. De øvrige forfatterne oppgir ingen interessekonflikter.

e-tab 1 finnes i artikkelen på www.tidsskriftet.no

\section{Litteratur}

1. Allender S, Scarborough P. Peto V et al. European cardiovascular disease statistics 2008. European Heart Network, 2008. www.ehnheart.org/content/ sectionintro.asp?level $0=1457$ (1.9.2008)

2. Dødsårsaksregisteret 2007. Oslo: Statistisk sentralbyrå, 2009. www.ssb.no/emner/03/01/10/ dodsarsak/arkiv/tab-2009-04-07-01.html (16.3.2010).

3. Norheim OF, Gjelsvik B, Kjeldsen SE et al. Nasjonale retningslinjer for individuell primærforebygging av hjerte- og karsykdommer. Oslo: Helsedirektoratet, 2009

4. Nicholson A, Kuper H, Hemingway H. Depression as an aetiologic and prognostic factor in coronary heart disease: a meta-analysis of 6362 events among 146538 participants in 54 observational studies. Eur Heart J 2006; 27: 2763-74.

5. Van der Kooy K, van Hout H, Marwijk H et al. Depression and the risk for cardiovascular diseases: systematic review and meta analysis. Int J Geriatr Psychiatry 2007; 22: 613-26.

6. van Melle JP, de Jonge P. Spijkerman TA et al. Prognostic association of depression following myocardial infarction with mortality and cardiovascular events: a meta-analysis. Psychosom Med 2004; 66: 814-22. 
7. Barth J, Schumacher M, Herrmann-Lingen C Depression as a risk factor for mortality in patients with coronary heart disease: a meta-analysis. Psychosom Med 2004; 66: 802-13.

8. Bonnet F, Irving K, Terra JL et al. Anxiety and depression are associated with unhealthy lifestyle in patients at risk of cardiovascular disease. Atherosclerosis 2005; 178: 339-44.

9. Rieckmann N, Gerin W, Kronish IM et al. Course of depressive symptoms and medication adherence after acute coronary syndromes. An electronic medication monitoring study. J Am Coll Cardiol 2006; 48: 2218-22

10. Writing Committee for the ENRICHD Investigators. Effects of treating depression and low perceived social support on clinical events after myocardial infarction: the Enhancing Recovery in Coronary Heart Disease patients (ENRICHD) randomized trial. JAMA 2003; 289: 3106-16

11. van Melle JP, de JP, Honig A et al. Effects of antidepressant treatment following myocardial infarction. Br J Psychiatry 2007; 190: 460-6

12. Glassman $\mathrm{AH}, \mathrm{O}^{\prime}$ Connor CM, Califf RM et al. Sertraline treatment of major depression in patients with acute MI or unstable angina. JAMA 2002; 288 701-9.

13. Lesperance F, Frasure-Smith N, Koszycki D et al. Effects of citalopram and interpersonal psychotherapy on depression in patients with coronary artery disease: the Canadian Cardiac Randomized Evaluation of Antidepressant and Psychotherapy Efficacy (CREATE) trial. JAMA 2007; 297: 367-79.

14. Taylor CB, Youngblood ME, Catellier D et al. Effects of antidepressant medication on morbidity and mortality in depressed patients after myocardial infarction. Arch Gen Psychiatry 2005; 62: 792-8.

15. Sauer WH, Berlin JA, Kimmel SE. Selective serotonin reuptake inhibitors and myocardial infarction. Circulation 2001; 104: 1894-8.

16. Sauer WH, Berlin JA, Kimmel SE. Effect of antidepressants and their relative affinity for the serotonin transporter on the risk of myocardial infarction. Circulation 2003; 108: 32-6.

17. Monster TBM, Johnsen SP, Olsen ML et al. Antidepressants and risk of first-time hospitalization for myocardial infarction: a population-based case-control study. Am J Med 2004; 117: 732-7.

18. Tata LJ, West J, Smith C et al. General population based study of the impact of tricyclic and selective serotonin reuptake inhibitor antidepressants on the risk of acute myocardial infarction. Heart 2005; 91: 465-71.

19. Tiihonen J, Lonnqvist J, Wahlbeck K et al. Antidepressants and the risk of suicide, attempted suicide, and overall mortality in a nationwide cohort. Arch Gen Psychiatry 2006; 63: 1358-67.

20. Naghavi M, Libby P. Falk E et al. From vulnerable plaque to vulnerable patient: a call for new definitions and risk assessment strategies: Part I. Circulation 2003; 108: 1664-72.

21. Marcovina SM, Crea F, Davignon J et al. Biochemical and bioimaging markers for risk assessment and diagnosis in major cardiovascular diseases: a road to integration of complementary diagnostic tools. J Intern Med 2007; 261: 214-34.

22. Hansson GK. Inflammation, atherosclerosis, and coronary artery disease. N Engl J Med 2005; 352: 1685-95.

23. Cao JJ, Arnold AM, Manolio TA et al. Association of carotid artery intima-media thickness, plaques, and C-reactive protein with future cardiovascular disease and all-cause mortality: the cardiovascular health study. Circulation 2007; 116: 32-8.

24. Miller AH, Maletic V, Raison CL. Inflammation and its discontents: The role of cytokines in the pathophysiology of major depression. Biol Psychiatry 2009; 65: $732-41$.

25. Howren MB, Lamkin DM, Suls J. Associations of depression with C-reactive protein, IL-1, and IL-6: A meta-analysis. Psychosom Med 2009; 71 : $171-86$

26. Miller $\mathrm{AH}$. Mechanisms of cytokine-induced behavioral changes: psychoneuroimmunology at the translational interface. Brain Behav Immun 2009; 23: $149-58$.

27. Arbelaez JJ, Ariyo AA, Crum RM et al. Depressive symptoms, inflammation, and ischemic stroke in older adults: a prospective analysis in the cardiovascular health study. J Am Geriatr Soc 2007; 55: 1825-30.
28. Empana JP, Sykes DH, Luc G et al. Contributions of depressive mood and circulating inflammatory markers to coronary heart disease in healthy European men: the prospective epidemiological study of myocardial infarction (PRIME). Circulation 2005; 111: 2299-305.

29. Schins A, Tulner D, Lousberg R et al. Inflammatory markers in depressed post-myocardial infarction patients. J Psychiatr Res 2005; 39: 137-44.

30. Whooley MA, Caska CM, Hendrickson BE et al. Depression and inflammation in patients with cor onary heart disease: findings from the Heart and Soul Study. Biol Psychiatry 2007; 62: 314-20.

31. Moorman AJ, Mozaffarian D, Wilkinson CW et al. In patients with heart failure elevated soluble TNFreceptor 1 is associated with higher risk of depression. J Card Fail 2007; 13: 738-43.

32. Brotman DJ, Golden SH, Wittstein IS. The cardiovascular toll of stress. Lancet 2007: 370 : 1089-100.

33. Hasler G, Drevets WC, Manji HK et al. Discovering endophenotypes for major depression. Neuropsychopharmacology 2004; 29: 1765-81.

34. Carney RM, Freedland KE, Veith RC. Depression, the autonomic nervous system, and coronary heart disease. Psychosom Med 2005; 67: 529-33.

35. Carney RM, Blumenthal JA, Freedland KE et al. Low heart rate variability and the effect of depression on post-myocardial infarction mortality. Arch Intern Med 2005; 165: 1486-91

36. Kamphuis MH, Geerlings MI, Dekker JM et al. Autonomic dysfunction: a link between depression and cardiovascular mortality? The FINE Study. Eur J Cardiovasc Prev Rehabil 2007; 14: 796-802.

37. Bonetti PO, Lerman LO, Lerman A. Endothelial dysfunction: a marker of atherosclerotic risk. Arterioscler Thromb Vasc Biol 2003; 23: 168-75.

38. Davi G. Patrono C. Platelet activation and atherothrombosis. N Engl J Med 2007; 357: 2482-94.

39. Choi BG, Vilahur G, Ibanez B et al. Measures of thrombosis and fibrinolysis. Clin Lab Med 2006; 26 $655-78$.

40. Deanfield JE, Halcox JPM, Rabelink TJM. Endothelial function and dysfunction: testing and clinical relevance. Circulation 2007; 115: 1285-95.

41. Danesh J, Lewington S, Thompson SG et al. Plasma fibrinogen level and the risk of major cardiovascular diseases and nonvascular mortality: an individual participant meta-analysis. JAMA 2005; 294: 1799-809.

42. Broadley AJ, Korszun A, Jones CJ et al. Arterial endothelial function is impaired in treated depression. Heart 2002; 88: 521-3.

43. Sherwood A, Hinderliter AL, Watkins LL et al. Impaired endothelial function in coronary heart disease patients with depressive symptomatology. J Am Coll Cardiol 2005; 46: 656-9.

44. Yang EH, Lerman S, Lennon RJ et al. Relation of depression to coronary endothelial function. Am J Cardiol 2007; 99: 1134-6.

45. Lesperance F, Frasure-Smith N, Theroux P et al. The association between major depression and levels of soluble intercellular adhesion molecule 1. interleukin-6, and C-reactive protein in patients with recent acute coronary syndromes. Am J Psychiatry 2004; 161: $271-7$.

46. Serebruany VL, Glassman AH, Malinin Al et al. Enhanced platelet/endothelial activation in depressed patients with acute coronary syndromes: evidence from recent clinical trials. Blood Coagul Fibrinolysis 2003; 14: 563-7.

47. Nemeroff CB, Musselman DL. Are platelets the link between depression and ischemic heart disease? Am Heart J 2000; 140: 57-62.

48. Serebruany VL, Glassman AH, Malinin Al et al. Platelet/endothelial biomarkers in depressed patients treated with the selective serotonin reuptake inhibitor sertraline after acute coronary events: the Sertraline AntiDepressant Heart Attack Randomized Trial (SADHART) platelet substudy. Circulation 2003; 108: 939-44.

49. Serebruany VL, Suckow RF, Cooper TB et al. Relationship between release of platelet/endothelial biomarkers and plasma levels of sertraline and $\mathrm{N}$-desmethylsertraline in acute coronary syndrome patients receiving SSRI treatment for depression. Am J Psychiatry 2005; 162: 1165-70.

50. von Kanel R. Platelet hyperactivity in clinical depression and the beneficial effect of antidepressant drug treatment: how strong is the evidence? Acta Psychiatr Scand 2004; 110: 163-77.
51. Pizzi C, Mancini S, Angeloni L et al. Effects of selective serotonin reuptake inhibitor therapy on endothelial function and inflammatory markers in patients with coronary heart disease. Clin Pharmacol Ther 2009; 86: 527-532

52. Hayley S, Poulter MO, Merali Z et al. The pathogenesis of clinical depression: stressor- and cytokine-induced alterations of neuroplasticity. Neuroscience 2005; 135: 659-78.

53. Caspi A, Sugden K, Moffitt TE et al. Influence of life stress on depression: moderation by a polymorphism in the 5-HTT gene. Science 2003; 301: 386-9.

54. Hamer M, Molloy GJ, Stamatakis E. Psychological distress as a risk factor for cardiovascular events. Pathophysiological and behavioral mechanisms. J Am Coll Cardiol 2008; 52: 2156-62.

55. Broadley AJ, Korszun A, Abdelaal E et al. Metyrapone improves endothelial dysfunction in patients with treated depression. J Am Coll Cardiol 2006; 48: $170-5$.

56. Gallagher P, Malik N, Newham J et al. Antiglucocorticoid treatments for mood disorders. Cochrane Database of Systematic Reviews 2008; nr.3, CD005168

57. Lichtman J, Bigger JT, Blumenthal J et al. Depression and coronary heart disease: recommendations for screening, referral and treatment. Circulation 2008; 118: 1768-75.

58. Farmakoterapi ved unipolar depresjon hos voksne og eldre. Oslo: Statens Legemiddelverk, 2005. www.legemiddelverket.no/templates/ InterPage_28553.aspx, (30.6.2009).

Manuskriptet ble mottatt 10.10. 2008 og godkjent 14.1. 2010. Medisinsk redaktør Siri Lunde. 